\title{
The Effect of Prolonged Intrauterine Hyperinsulinemia on Iron Utilization in Fetal Sheep
}

\author{
MICHAEL K. GEORGIEFF, JOHN A. WIDNESS, MARLA M. MILLS, AND \\ BARBARA S. STONESTREET
}

\begin{abstract}
Division of Neonatal Medicine [M. K. G., M. M. M.], Department of Pediatrics, University of Minnesota Hospital and Children's Hospital of St. Paul, Minneapolis/St. Paul, Minnesota 55455; Division of Neonatology [J. A. W.], Department of Pediatrics, University of Iowa, Iowa City, Iowa 52242; and Brown University Program in Medicine [B. S. S.J, Department of Pediatrics, Women and Infants' Hospital of Rhode Island, Providence, Rhode Island 02905-2401
\end{abstract}

\begin{abstract}
Newborn infants of poorly controlled insulindependent diabetic mothers demonstrate a redistribution of iron from serum and tissue stores into red blood cells. These changes may be due to increases in iron utilization during augmented $\mathrm{Hb}$ synthesis, which compensates for chronic intrauterine hypoxemia induced by prolonged fetal hyperinsulinemia. We tested this hypothesis by measuring plasma iron, total iron-binding capacity, percent iron-binding capacity saturation (total iron-binding capacity saturation), $\mathrm{Hb}$ concentration, total red cell $\mathrm{Hb}$, and total red cell iron in the arterial blood of 11 chronically instrumented fetal sheep after 7-12 d of infusion with $15 \mathrm{U} /$ day of insulin $(n=5)$ or placebo $(n=6)$. The insulin-infused fetal sheep had higher mean \pm SD plasma insulin concentrations $(448$ \pm 507 versus $11 \pm 8 \mathrm{mU} / \mathrm{L} ; p<0.001)$ and lower arterial oxygen saturations $(38 \pm 7$ versus $54 \pm 9 \% ; p<0.02)$. The insulin-infused group had a lower mean plasma iron concentration $(20.8 \pm 10.9$ versus $42.1 \pm 14.7 \mu \mathrm{M} / \mathrm{L} ; p<0.02)$ and total iron-binding capacity saturation $(36 \pm 20$ versus $64 \pm 22 \% ; p<0.02)$ and a higher total red cell $\mathrm{Hb}(45.4$ \pm 8.7 versus $32.6 \pm 8.8 \mathrm{~g} ; p<0.02$ ) and total red cell iron content $(154 \pm 29$ versus $111 \pm 29 \mathrm{mg} ; p<0.02)$ when compared with the placebo group. Seven to $12 \mathrm{~d}$ of intrauterine hyperinsulinemia decreases serum iron and increases total red cell iron, most likely by stimulating increased $\mathrm{Hb}$ synthesis in response to low arterial oxygen saturation. Hyperinsulemia may play a major role in the altered iron metabolism in newborn infants of diabetic mothers. (Pediatr Res 26:467-469, 1989)
\end{abstract}

\section{Abbreviations}

TIBC, total iron-binding capacity

TIBC saturation, TIBC saturation

FEP, free erythrocyte protoporphyrin

$\mathrm{CaO}_{2}$, calculated arterial oxygen content

Infants of insulin-dependent diabetic mothers who are large for dates and hypoglycemic at birth rate are at high risk for the hematologic manifestations of iron deficiency, including abnor-

Received March 24, 1989; accepted June 29, 1989. Correspondence and reprint requests Michael K Georgieff, M.D., Box 39 UMHC, University of Minnesota Hospital and Clinic, Harvard Street at East River Road, Minneapolis, MN 55455.

Hospital and Clinic, Harvard Street at East River Road, Minneapolis, MN 55455. Diabetes Center Grant P-50 HD1 1343 and a grant from Ross Laboratories. mally low cord blood serum ferritin and iron concentrations and abnormally high cord blood serum transferrin, total iron-binding capacity and FEP concentrations (1-3). These alterations imply aberrations in fetal iron metabolism ranging from depletion of iron stores (decreased ferritin) to ineffective erythropoiesis (increased FEP) (4). Many infants of diabetic mothers are polycythemic at birth (5), which means that fetal iron delivery to red blood cells must increase to support this augmented $\mathrm{Hb}$ synthesis.

The mechanism of altered iron metabolism in these infants has not been studied. We have hypothesized that the changes most likely represent redistribution of iron from tissue stores into red cells for the compensatory increase in $\mathrm{Hb}$ synthesis associated with chronic intrauterine hypoxemia (2). The latter is thought to be due to increased fetal oxygen consumption induced by both chronic intrauterine hyperinsulinemia and hyperglycemia (6-8), but may also be due to the effect of significant vascular disease on oxygen or nutrient transfer.

This study tests the hypothesis that prolonged hyperinsulinemia in fetal sheep without hyperglycemia or underlying placental vascular disease results in sufficient arterial blood oxygen desaturation to cause a shift of iron from the plasma into the red cells.

\section{MATERIALS AND METHODS}

Animal preparation. Eleven mixed-breed Eastern ewes with time-dated pregnancies between 122 and $126 \mathrm{~d}$ gestation were anesthetized with intravenous ketamine and local lidocaine, and had catheters placed into the inferior vena cavae and abdominal aortae of their fetuses via the pedal arteries and veins as previously described (9). Plasma samples for this study were obtained from animals enrolled in a larger series of studies assessing the sequential effects of hyperinsulinemia on fetal blood volume and fatty acid metabolism, and in which plasma was available at the time of death for iron analysis (9-11).

Experimental protocol. Four to $6 \mathrm{~d}$ after surgery, the fetal sheep were assigned to an insulin-infused $(n=5)$ or placeboinfused $(n=6)$ group. Insulin-infused fetal animals received 15 U/day of Iletin II (Eli Lilly and Co., Indianapolis, IN) in diluent via a fetal vein $(9-11)$. Placebo-infused animals received the diluent. Fetal arterial samples were obtained for plasma insulin, glucose, iron, and TIBC, oxygen saturation, $\mathrm{Hb}$, and hematocrit after 7 to $12 \mathrm{~d}$ of infusion. Maternal arterial plasma was also obtained for analysis of plasma iron and TIBC concentrations.

Biochemical analysis. Plasma insulin concentrations were measured by a double antibody RIA (12), plasma glucose using a Yellow Springs Instrument Glucose Analyzer (model 23A, Yellow Springs, $\mathrm{OH})$, fetal oxygen saturations and Hb concen- 
trations with a Radiometer Hemoximeter (model OSM2, Copenhagen, Denmark), and fetal hematocrits by a microhematocrit method. Plasma samples for iron determination were centrifuged immediately and the plasma frozen at $-20^{\circ} \mathrm{C}$ until analysis. Plasma iron concentration was determined by direct iron assay using the chromophore Ferene (Dimension Clinical Chemistry System, E.I. DuPont Co., Wilmington, DE). Plasma TIBC was measured using the same chromophore following elution from an alumina column (Dimension Clinical Chemistry System, E.I. DuPont Co., Wilmington, DE). Interassay variabilites for the iron and iron-binding capacity assays within the range of serum samples tested were $<3 \%$. All analyses were done in duplicate.

Determination of red cell volumes was necessary for the calculation of total red cell $\mathrm{Hb}$ and iron contents. Red cell volumes were measured using ${ }^{99 \mathrm{~m}}$ Tc autologous-labelled fetal red cells (13, 14). Briefly, $4 \mathrm{~mL}$ of fetal whole blood in acid-citrate dextrose solution was incubated for $15 \mathrm{~min}$ each with Sn-pyrophosphate and subsequently ${ }^{99 \mathrm{~m}} \mathrm{Tc}$. The red cells were washed, resuspended in normal saline and administered in a bolus of $5 \mathrm{~mL}$ to the fetus. Fetal arterial blood was sampled at 10 and $20 \mathrm{~min}$, the samples were weighed and radioactivity counted (Traycor analytic sample changer, model 1185, Elk Grove, IL). Fetal red cell volume $(\mathrm{mL})$ was calculated by dividing the total cpm of the standard fetal red cells injected by the $\mathrm{cpm} / \mathrm{mL}$ of the fetal red cells sampled. Fetal blood volume was calculated by dividing the measured red cell volume by the fetal hematocrit. Values for 10 and $20 \mathrm{~min}$ were not different and were averaged. Fetal arterial oxygen contents $\left(\mathrm{CaO}_{2}\right)$ were calculated as previously described (15).

Serum and red cell iron calculations. Percent TIBC saturation was calculated by dividing plasma iron by TIBC values and multiplying by 100 . Total red cell $\mathrm{Hb}$ was calculated by multiplying fetal blood volume by the $\mathrm{Hb}$ concentration. The total red cell iron content was calculated by multiplying total red cell $\mathrm{Hb}$ by $3.4 \mathrm{mg}$ of elemental iron/g Hb.

Statistical analysis. We compared the mean plasma insulin concentrations, glucose concentrations, oxygen saturations. $\mathrm{CaO}_{2}$, plasma irons, TIBC, TIBC saturations, $\mathrm{Hb}$ concentrations, total red cell $\mathrm{Hb}$, and total red cell iron contents of the insulininfused group with the values of the placebo group at the end of the infusion period using the two-tailed Student's $t$ test with significance set at a $p<0.05$. All values are presented as mean $\pm 1 \mathrm{SD}$.

\section{RESULTS}

The two groups had comparable gestational ages, number of days of infusion, and plasma glucose concentrations (Table 1). After 7-12 d, the insulin-infused group had a significantly higher plasma insulin concentration and significantly lower arterial oxygen saturation but similar $\mathrm{CaO}_{2}$ when compared with the placebo-infused group.

Mean plasma iron concentration and percent iron-binding saturation were significantly lower in the insulin-infused group than in the placebo group and were accompanied by a signifi-

Table 1. Gestational age, infusion time, plasma glucose and insulin concentrations, and fetal oxygen characteristics of insulin-and placebo-infused sheep at time of assessment of iron status (mean $\pm S D$ )

\begin{tabular}{lccc}
\hline & $\begin{array}{c}\text { Insulin } \\
(n=5)\end{array}$ & $\begin{array}{c}\text { Placebo } \\
(n=6)\end{array}$ & $p$ \\
\hline Gestational age (d) & $135 \pm 1$ & $133 \pm 2$ & $\mathrm{NS}$ \\
Time of infusion (d) & $11 \pm 1$ & $9 \pm 2$ & $\mathrm{NS}$ \\
Plasma insulin (mU/L) & $448 \pm 507$ & $11 \pm 8$ & $<0.001$ \\
Plasma glucose (mmol/L) & $0.50 \pm 0.17$ & $0.74 \pm 0.28$ & $\mathrm{NS}$ \\
Arterial oxygen saturation & $38 \pm 7$ & $54 \pm 9$ & $<0.02$ \\
$\quad(\%)$ & $64 \pm 16$ & $76 \pm 21$ & $\mathrm{NS}$ \\
\hline
\end{tabular}

cantly higher total red cell iron content (Fig. 1). TIBC was similar in both groups. The blood volume of the insulin-infused group was $0.447 \pm 0.073 \mathrm{~L}$ and was significantly more than the 0.345 $\pm 0.062 \mathrm{~L}$ value of the control group. The total red cell $\mathrm{Hb}$ content was significantly greater in the insulin-infused group, although the mean $\mathrm{Hb}$ and hematocrit concentrations of the two groups were not different (Table 2).

The iron status of the ewes was measured in the arterial plasma of four animals in which the fetus had been infused with insulin and five in which the fetus had been infused with placebo. The mean maternal plasma iron of the insulin-infused fetal animals was $45.6 \pm 8.2 \mu \mathrm{M} / \mathrm{L}$, with a TIBC saturation of $73 \pm 20 \%$. These values were not different from the maternal plasma iron $(46.7 \pm 6.6 \mu \mathrm{m} / \mathrm{L})$ and TIBC saturation $(71 \pm 17 \%)$ of the placebo-infused fetuses. There also were no differences between these maternal values and those of the placebo-infused fetal sheep.

\section{DISCUSSION}

Our study demonstrates that 7 to $12 \mathrm{~d}$ of hyperinsulinemia significantly alters the iron status of late gestation fetal sheep. Prolonged fetal insulin infusion is associated with a decreased plasma iron concentration and iron-binding saturation, increased total red cell $\mathrm{Hb}$ and iron content, and lower fetal arterial oxygen saturation. These results suggest that iron is transferred from plasma into red cells to support accelerated $\mathrm{Hb}$ synthesis in response to prolonged fetal hypoxemia. The study supports our hypothesis that chronic fetal hypoxemia associated with prolonged fetal hyperinsulinemia is a likely etiology of the altered iron status described in newborn infants of diabetic mothers (13).

We have previously proposed two potential mechanisms to account for the serum iron changes seen in infants of diabetic mothers. These include increased iron utilization during hypoxemia-augmented erythropoiesis and impaired placental iron transfer secondary to diabetic placental vascular disease $(1,3)$. The hyperinsulinemia sheep model allowed us to eliminate placental vascular disease as a variable and to demonstrate that

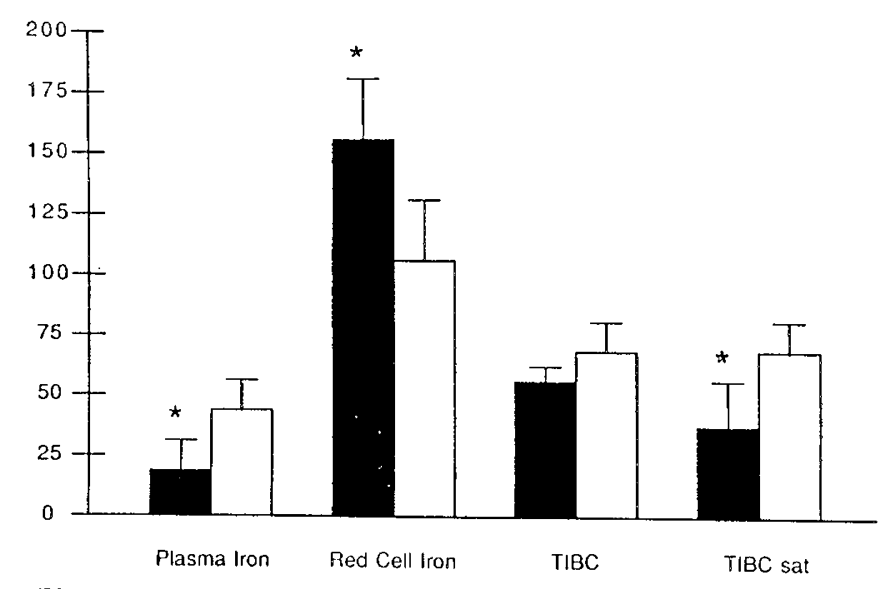

Fig. 1. Iron status of insulin- $(\square)$ and placebo- $(\square)$ infused fetal sheep. Plasma iron and TIBC are expressed as $\mu \mathrm{M} / \mathrm{L}$, red cell iron as $\mathrm{mg}$, and TIBC saturation as a percentage. Values are mean \pm SD. ${ }^{*} P<0.02$ versus placebo-infused group.

Table 2. Hematologic status of insulin-and placebo-infused fetal sheep at time of iron analysis (mean $\pm S D$ )

\begin{tabular}{lccc}
\hline & $\begin{array}{c}\text { Insulin } \\
(n=5)\end{array}$ & $\begin{array}{c}\text { Placebo } \\
(n=6)\end{array}$ & $p$ \\
\hline $\mathrm{Hb}(\mathrm{g} / \mathrm{L})$ & $101 \pm 7$ & $96 \pm 15$ & $\mathrm{NS}$ \\
Hematocrit & $0.350 \pm 0.023$ & $0.326 \pm 0.053$ & $\mathrm{NS}$ \\
Total red cell Hb $(\mathrm{g})$ & $45.4 \pm 8.7$ & $32.6 \pm 8.8$ & $<0.02$ \\
\hline
\end{tabular}


hyperinsulinemia is an independent variable that affects fetal iron utilization.

The specific mechanism by which fetal hyperinsulinemia alters iron utilization is unknown. We speculate that the driving force for the increased red cell iron utilization seen in our fetal sheep was the accelerated $\mathrm{Hb}$ synthesis associated with the significant decrease in arterial oxygen saturation. Chronic fetal hyperinsulinemia causes arterial oxygen desaturation $(8,16)$, most likely by increasing fetal oxygen consumption (8). Hyperinsulinemia increases fetal erythropoiesis in rhesus monkeys, most likely in response to hypoxemia (6), although hyperinsulinemia may also independently stimulate erythropoiesis (17). Expansion of the red cell mass in response to hypoxemia with its attendant increase in $\mathrm{Hb}$ synthesis results in increased utilization of available iron $(18,19)$.

In our study the insulin-infused animals had $40 \%$ more total $\mathrm{Hb}$ in red cells than the placebo-infused group. This difference in $\mathrm{Hb}$ content requires the delivery of an additional $44 \mathrm{mg}$ of elemental iron to the erythrocytes of the insulin-infused fetus. Iron for additional $\mathrm{Hb}$ is potentially available from several sources, including fetal plasma, fetal tissue stores, and maternal plasma. Further research is necessary to quantitate the relative contributions of these sources during pathologic states that augment fetal erythropoiesis. Fetal sheep have relatively low tissue iron stores (20), a factor that may potentially limit the amount of elemental iron available from this source during a sudden increase in $\mathrm{Hb}$ synthesis and may explain the rapidity with which a significant decrease in plasma iron was observed in our study.

The time course over which fetal iron status changed was consistent with a previous model of hematologic adaptations to chronic arterial oxygen desaturation in neonatal sheep (21), and reflects the amount of time required to incorporate iron into $\mathrm{Hb}$ in third trimester fetal sheep (19). As in hypoxemic neonatal sheep (21), arterial oxygen content values at 7 to $12 \mathrm{~d}$ were similar in the two groups, implying that the $40 \%$ increase in total red cell $\mathrm{Hb}$ compensated for the $30 \%$ decrease in arterial oxygen saturation. The cost of this compensation was lower serum iron concentrations and iron-binding saturations. An analogous finding in newborn human infants has been described where cord serum ferritin concentrations, representing storage iron, are inversely related to cord $\mathrm{Hb}$ concentrations (22).

Although total red cell $\mathrm{Hb}$ was significantly higher in the insulin-infused animals, the slightly higher $\mathrm{Hb}$ and hematocrit concentrations were not significantly different than the placeboinfused group. The lack of a significant difference between the two groups may have been due to a $\beta$ error. Alternatively, plasma $\mathrm{Hb}$ concentrations may take longer than the duration of our study period to rise, because plasma volume also appears to vary with the duration and severity of hypoxemia (23-25).

Neonatal iron deficiency on the basis of maternal iron deficiency is thought to be relatively rare because fetal iron status remains normal unless the mother is profoundly iron deficient (26). Nevertheless, the long-term consequences of decreased fetal plasma iron concentrations and red cell iron sequestration on nonheme tissues in fetal conditions characterized by accelerated heme synthesis are of potential importance to the developing human during late gestation. Iron deficiency during early postnatal life has been known to affect the development and function of multiple organ systems, including the central nervous system $(27,28)$. Further studies are necessary to understand the effect of prolonged fetal hyperinsulinemia on iron stores and iron delivery to nonheme tissues in the fetus.

This study in hyperinsulinemic fetal sheep supports the hypothesis that hyperinsulinemia is at least in part responsible for the hematologic manifestations of altered iron status previously described in newborn infants of insulin-dependent diabetic mothers and presents further evidence that strict maternal glycemic control, which may prevent fetal hyperinsulinemia during the third trimester, is critical for fetal and neonatal well being.
Acknowledgments. The authors acknowledge the excellent technical assistance of Ann Beauregard, Dennis Berard, and Edrie Murphy as well as the continued support of Dr. William Oh during these studies. We also thank George L. Ross, M.S., for the development of the mechanized sheep lift, which was indispensable to the surgical preparation of the fetal sheep.

\section{REFERENCES}

1. Chockalingam UM, Murphy E, Ophoven JC, Weisdorf SA, Georgieff MK 1987 Cord transferrin and ferritin values in newborn infants at risk for prenatal uteroplacental insufficiency and chronic hypoxia. J Pediatr 111:283-286

2. Amarnath UM, Ophoven JJ, Mills MM, Murphy EL, Georgieff MK 1989 The relationship between decreased iron stores, serum iron and neonatal hypoglycemia in large-for-dates newborn infants. Acta Paediatr Scand (in press)

3. Georgieff MK, Amarnath UM, Landon MB, Mills MM, Ophoven JJ 1988 Newborn iron status of infants of diabetic mothers (IDMs). Pediatr Res 23:390(abstr)

4. Dallman PR 1986 Biochemical basis for the manifestations of iron deficiency. Ann Rev Nutr 6:13-40

5. Mimouni F, Miodovnik, M, Siddiqi TA, Butler JB, Holdroyde J, Tsang RC 1986 Neonatal polycythemia in infants of insulin-dependent diabetic mothers. Obstet Gynecol 68:370-372

6. Widness JA, Susa JB, Garcia JF, Singer OB, Sehgal P, Oh W, Schwartz R, Schwartz HC 1981 Increased erythropoiesis and elevated erythropoietin in infants born to diabetic mothers and in hyperinsulinemic rhesus fetuses. $\mathbf{J}$ Clin Invest 67:637-642

7. Philipps AF, Porte PJ, Strabinsky S, Rosenkranz TS, Raye JR 1984 Effects of chronic fetal hyperglycemia upon oxygen consumption in the ovine uterus and conceptus. $J$ Clin Invest 74:279-286

8. Milley JR, Papacostas JS, Tabata BK 1986 Effect of insulin on uptake of metabolic substrates by the fetus. Am J Physiol 231:E349-E359

9. Stonestreet BS, Ogburn PL, Goldstein M, Oh W, Widness JA 1989 Effects of chronic fetal hyperinsulinemia on plasma arachidonic acid and prostaglandin concentrations. Am J Obstet Gynecol (in press)

10. Stonestreet BS, Goldstein M, Oh W, Widness JA 1987 The effects of prolonged hyperinsulinemia on red cell mass in fetal sheep. Pediatr Res 21:378(abstr)

11. Stonestreet BS, Goldstein M, Oh W, Widness JA. Effects of prolonged hyperinsulinemia on erythropoiesis in fetal sheep. Am J Physiol (in press)

12. Hales CN, Randle PH 1963 Immunoassay of insulin with insulin antibody precipitates. Biochem J $88: 137-146$

13. Brace RA 1983 Blood volume and its measurement in the chronically catheterized sheep fetus. Am J Physiol 244:H487-H494

14. Brace RA 1984 Blood volume in the fetus and methods for its measurement. In: Nathanielsz PW (ed) Animal Models in Fetal Medicine. Perinatology Press, Ithaca, NY, pp 1-36

15. Lister G, Walker TK, Versmold HT, Dallman PR, Rudolph AM 1979 Oxygen delivery in lambs: cardiovascular and hematologic development. Am J Physiol 237:H668-675

16. Carson BS, Philipps AF, Simmons MA, Battaglia FC, Meschia G 1980 Effects of sustained insulin infusion upon glucose uptake and oxygenation of the ovine fetus. Pediatr Res 14:147-152

17. Dainak N, Kreczko S 1985 Interactions of insulin, insulin-like growth factor II and platelet-derived growth factor on erythropoietic culture. J Clin Invest 76:1237-1242

18. Dallman PR 1987 Iron deficiency and related nutritional anemias. In: Nathan DG, Oski FA (eds) Hematology of Infancy and Childhood, 3rd ed. WB Saunders, Philadelphia, pp 301-302

19. Reynafarje C, Lozano R, Valdivieso J 1959 The polycythemia of high altitudes: Iron metabolism and related aspects. Blood 14:433-455

20. Hoskins FH, Hansard SL 1964 Placental transfer and fetal tissue iron utilization in sheep. J Nutrition 83:10-14

21. Teitel D, Sidi D, Bernstein D, Heymann MA, Rudolph AM 1985 Chronic hypoxemia in the newborn lamb: cardiovascular, hematopoietic, and growth adaptations. Pediatr Res 19:1004-1010

22. McPhail AP, Charlston RW, Bothwell TH, Torrance JD 1980 The relationship between maternal and infant iron status. Scand J Haematol 25:141-150

23. Picon-Reategui E, Lozano R, Valdivieso J 1961 Body composition at sea level and high altitudes. J Appl Physiol 16:589-592

24. Miles DS, Bransford DR, Horvath SM 1981 Hypoxia effects on plasma volume shifts at rest, work, and recovery in supine position. J Appl Physiol 51:148153

25. Yao AC, Lu T, Castellanos R, Matanic BP 1978 Effect of prenatally and postnatally induced hypoxia on blood volume of newborn lambs. Life Sci 22:931-936

26. Woodruff CW, Bridgeforth EB 1953 Relationship between the hemogram of the infant and that of the mother during pregnancy. Pediatrics 12:681-685

27. Oski FA 1979 The nonhematologic manifestations of iron deficiency. Am J Dis Child 133:315-322

28. Lozoff B, Brittenham GM, Wolf AW, McClish DK, Kuhnert PM, Jimenez E Jimenez J, Mora LA, Gomez I, Krauskopf 1987 Iron deficiency anemia and iron therapy effects on infant developmental test performance. Pediatrics 79:981-995 